\title{
PENGARUH KEPATUHAN DAN MOTIVASI PENDERITA TB PARU TERHADAP TINGKAT KESEMBUHAN PENGOBATAN DI PUSKESMAS TANJUNG MORAWA KABUPATEN DELI SERDANG TAHUN 2017
}

\author{
Reni Aprinawaty Sirait, ${ }^{1}$ Imelda J Verawati Lubis $^{2}$ \\ Institut Kesehatan MEDISTRA Lubuk Pakam \\ Jl. Sudirman No. 38 Lubuk Pakam Kab . Deli Serdang (20512) \\ Sumatera Utara. Telp (061) 7952234, Fax (061) 7972234 \\ Email: renisirait82@yahoo.com
}

\begin{abstract}
Tuberculosis (TB) is one of the infectious disease remains a significant health problem for people the world till now, including Indonesia. Tanjung Morawa Health Center is clinic that the lowest cure rate of 34 health centers in Deli Serdang district. The number of patients with Pulmonary TB positive BTA at Deli Serdang district by the Year 2014 many as 142 people with cure rate 75,79\% In year 2015, there were 124 patients with Pulmonary TB positive BTA but cure rate $63,5 \%$.. This means decreasing of cure rate in Deli Serdang district and did not reach the target yet was set at least $85 \%$. This type of research using explanatory research aims to explain the effect of adherence and motivation cure level of pulmonary tuberculosis treatment at Tanjung Morawa. The population were all patients with positive BTA pulmonary TB with a sample size of 21 people. The results of bivariat statistic test showed variables which influence treatment of Pulmonary TB cure rate, patient compliance $(p=0.002)$, the family support/PMO $(p=0.003)$ and staff support $(p=0.008)$. For increase TB patients awareness need IEC about pulmonary tuberculosis diseases, extension or counseling patients that patients more understand about their diseases and responsible on their recovery.
\end{abstract}

Keywords : Pulmonary TB cure, Compliance and Motivation.

\section{PENDAHULUAN}

Tuberculosis paru (TB paru) merupakan masalah kesehatan masyarakat yang masih menjadi tantangan global karena diketahui sepertiga penduduk dunia telah terinfeksi oleh Mycobacterium tuberculosa (WHO, 2011). Data pada tahun 2012 tercatat bahwa angka notifikasi kasus semua kasus baru sebesar 132 per 100.000 penduduk dan BTA positif baru sebesar 82 per 100.000 penduduk serta angka keberhasilan pengobatan sebesar 91\% (Kemenkes, 2013).

Di Indonesia penyakit TB termasuk penyakit pembunuh nomor satu diantara penyakit menular dan menempati urutan ketiga dalam kategori sepuluh penyakit pembunuh tertinggi di Indonesia. Indonesia merupakan negara pertama diantara high burden countris (HBCs) di wilayah South-East Asian Region (SEARO, yang mampu mencapai target global TB untuk deteksi kasus $(70 \%)$ dan keberhasilan pengobatan (85\%) pada tahun 2006. Namun beban TB di Indonesia masih sangat tinggi mengingat setiap tahun masih ada 2 per 1000 penduduk Indonesia sebagai kasus baru. Setiap tahun terdapat 178 orang perhari meningggal karena TB (Kemenkes, 2013).

TB paru masih menjadi masalah besar baik di Indonesia maupun di dunia. TB paru telah menyebabkan kematian 2 juta orang pertahun dan $9 \%$ kematian terjadi di negara-negara berkembang. Diperkirakan 0,3\% dari penduduk Indonesia menderita TB paru dan sebagian besar menyerang kelompok usia produktif yang 
mengakibatkan penderita kehilangan waktu kerja 3-4 bulan pertahun, sehingga penderita dan keluarga kehilangan $20-30 \%$ pendapatan rumah tangga.

Berdasarkan Global Tuberculosis Control (GTC), Organisasi Kesehatan Dunia (WHO) memperediksi Prevalensi TB paru di dunia sekitar 14 juta kasus, kemudian 9,4 juta kasus baru TB paru. Pada tahun 2009 terdapat 1,7 juta orang meninggal yang diakibatkan oleh TB paru. Kasus Kejadian TB tingkat global diprediksikan mengalami penurunan menjadi 137 kasus kejadian per 100.000 jumlah penduduk pada tahun 2009, Kemudian setelah kasus kejadian ini memuncak pada tahun 2014 sekitar 142 kasus kejadian per 100.000 jumlah penduduk. Namun begitu, penurunan angka kasus kejadian ini dianggap masih dalam kategori terlalu lambat.

Secara global, persentase penduduk yang sudah berhasil ditangani mencapai level tertinggi $86 \%$ pada saat tahun 2008. Pada umumnya kasus kejadian TB ini sering dijumpai di Asia Tenggara, Afrika dan Wilayah Pasifik Barat (Kemenkes RI, 2010). Berdasarkan laporan dari Organisasi Kesehatan Dunia (WHO) dalam Global Tuberculosis Report 2015, Indonesia menempati urutan kedua tertinggi di dunia sebagai kategori dalam kasus penderita TB setelah negara India yaitu sebanyak $10 \%$ dari total kasus TB di dunia. Tingkat risiko terpapar penyakit TB di Indonesia berkisar yaitu antara $1,7 \%$ sampai $4,4 \%$. Kemudian Secara nasional, Jenis Penyakit ini bisa membunuh sekitar 67.000 orang setiap tahunnya dan setiap hari sekitar 183 orang yang meninggal akibat dari jenis penyakit ini di Indonesia (Walgito, 2009).

Berdasarkan data kesehatan di Indonesia yang dilaporkan oleh Kemenkes RI 2013-2015 Jumlah angka kesembuhan TB paru di Indonesia menurut Kemenkes RI tahun 2013-2015 terdapat 161.365 jiwa atau sebesar $82,8 \%$ pada tahun 2013 , sedangkan pada tahun 2014 sebanyak 145.720 jiwa atau sebesar 74,2\% dan pada tahun 2015 sebanyak 193.320 jiwa atau sebesar $78 \%$.
Diketahui bahwa dari data tersebut terdapat penurunan angka kesembuhan TB dengan angka tersebut ternyata masih belum mencapai target yang sudah ditentukan oleh WHO yaitu sekitar 85\% (Kemenkes RI, 2016).

Berdasarkan data kesehatan yang sudah dilaporkan oleh Dinas Kesehatan Provinsi Sumatra Utara 2013-2015 menjelaskan bahwa jumlah kasus penderita TB paru yang terdata pada tahun 2013 adalah sebesar 22.361 jiwa manusia Sumatera Utara atau sebesar $82,7 \%$ dengan angka prevalensi sekitar 169 per 100.000 jumlah penduduk Sumatera Utara kemudian pada tahun 2014 terjadi penurunan jumlah angka kasus kejadian penderita TB Paru dengan jumlah 21.954 jiwa atau sekitar $72,29 \%$ dengan angka prevalensi sekitar 156,3 per 100.000 jumlah penduduk di Sumatera Utara.

Pada tahun 2015 terjadi peningkatan jumlah angka kasus kejadian penderita TB Paru di Sumatera Utara sebanyak 24.052 jiwa atau sebesar $76,35 \%$ dengan prevalensi 174,71 per 100.000 jumlah penduduk di daerah Sumatera Utara (Dinkes Provinsi Sumut, 2015). Beberapa variabel yang mempengaruhi terjadinya proses kesembuhan dalam pengobatan penderita TB paru di Wilayah kota Ambon yaitu Pengawas Menelan Obat (PMO), kepatuhan atas berobat oleh penderita TB paru dan juga efek samping dari obat tersebut (Penelitian Amiruddin, 2006).

Alasan mendasar terjadinya gagal dalam pengobatan yaitu pasien tidak mau meminum obatnya secara teratur dalam jangka waktu yang sudah diharuskan. Alasan pasien tidak meminum obat yaitu biasanya bosan harus meminum banyak obat setiap hari dalam jangka waktu beberapa bulan, oleh karena itu pasien cenderung memberhentikan pengobatan. (Smeltzer \& bare dalam Sujana, 2012).

Perilaku penderita untuk menjalani pengobatan secara teratur dipengaruhi beberapa faktor yaitu perilaku yang dipengaruhi faktor kepatuhan, motivasi, kepercayaan dan sikap positif, tersedianya 
sarana dan prasarana yang diperlukan dan terdapat dorongan yang dilandasi kebutuhan yang dirasakan (Mantra dalam Sujana, 2012).

Kabupaten Deli Serdang terdiri oleh 22 Kecamatan dengan 34 Puskesmas. Menurut data kesehatan yang dilaporkan oleh Dinas Kesehatan Kabupaten Deli Serdang 20132015, jumlah angka penderita TB paru di Kabupaten Deli Serdang tahun 2013 yaitu sebanyak 2.616 jiwa atau sebesar $75,79 \%$ dengan prevalensi 142 per 100.000 penduduk, tahun 2014 telah mengalami peningkatan sebanyak 2.886 jiwa atau sebesar $81,2 \%$ dengan prevalensi sebesar 124 per 100.000 penduduk dan tahun 2015 sebanyak 2.992 jiwa atau sebesar $82,9 \%$ dengan prevalensi 129 per 100.000 penduduk (Dinkes Kab. Deli serdang, 2016).

Tujuan penelitian yaitu untuk menganalisis ada tidaknya pengaruh kepatuhan dan motivasi penderita TB Paru terhadap tingkat kesembuhan pengobatan di Puskesmas Tanjung Morawa Kab. Deli Serdang Tahun 2017. Pendekatan pemecahan masalahan dari penelitian tersebut yaitu Menurunnya tingkat kesembuhan penderita kasus TB Paru pada tahun 2014 75,79\% menjadi 63,5\%, dimana puskesmas di kecamatan lainnya rata-rata mencapai angka kesembuhan lebih besar $85 \%$ sesuai dengan target yang telah ditetapkan.

Survei pendahuluan peneliti tersebut diketahui terdapat 45\% penderita TB Paru yg kurang patuh dan kurangnya motivasi berobat. Salah satu penyebabnya adalah karena penderita merasa bosan dan lelah dalam menjalani pengobatan.

Rendahnya angka cakupan dari kesembuhan menimbulkan dampak negatif pada kesehatan masyarakat dan keberhasilan pencapaian program, dikarenakan masih memberi peluang untuk terjadinya proses penularan penyakit TB paru pada anggota keluarga dan masyarakat sekitarnya.Faktor yang lain adalah terjadinya resistensi kuman TB paru terhadap Obat Anti Tuberkulosis (OAT), sehingga dapat menambah distribusi dari penyakit TB paru yang dapat meningkatkan angka kesakitan dan angka kematian akibat TB paru.

\section{METODE PENELITIAN}

Jenis dari penelitian ini yaitu dengan menggunakan tipe explanatory research yang berguna untuk menjelaskan pengaruh kepatuhan dan motivasi (dukungan keluarga/PMO dan dorongan petugas) terhadap tingkat kesembuhan pengobatan Tuberkulosis paru di Puskesmas Tanjung Morawa Kabupaten Deli Serdang Tahun 2017. Adapun Lokasi penelitian di Puskesmas Tanjung Morawa Kabupaten Deli serdang. Populasi dalam penelitian ini yaitu seluruh penderita TB paru BTA positif yang mengikuti program DOTS di Puskesmas Tanjung Morawa berjumlah 21 responden. Pengambilan sampel dengan metode Total Sampling yaitu 21 responden. Teknik analisis didalam penelitian ini yaitu analisis univariat dan bivariat.

\section{HASIL PENELITIAN}

Tabel 1. Distribusi Responden Berdasarkan Kategori Kepatuhan Penderita

\begin{tabular}{lll}
\hline Kepatuhan & Frekuensi & $(\%)$ \\
\hline Patuh & 15 & 71,4 \\
\hline Tidak patuh & 6 & 28,6 \\
\hline Jumlah & 21 & 100
\end{tabular}

Berdasarkan tabel di atas, diketahui bahwa responden terbanyak kategori patuh yaitu 15 responden $(71,4 \%)$ dan kategori tidak patuh yaitu 6 responden $(28,6 \%)$.

Tabel 2. Distribusi Responden Berdasarkan Kategori Dukungan Keluarga

\begin{tabular}{lcc}
\hline $\begin{array}{c}\text { Dukungan } \\
\text { Keluarga }\end{array}$ & Frekuensi & $(\%)$ \\
\hline Buruk & 6 & 28,6 \\
\hline Sedang & 7 & 33,3 \\
\hline Baik & 8 & 38,1 \\
\hline Jumlah & 21 & 100 \\
\hline
\end{tabular}

Berdasarkan tabel diatas, menunjukkan bahwa 8 responden $(38,1 \%)$ menerima 
dukungan keluarga kategori baik, kategori sedang sebanyak 7 responden $(33,3 \%)$, dan kategori buruk $6(28,6 \%)$ dalam dukungan keluarga/PMO.

Tabel 3. Distribusi Responden Berdasarkan Dorongan Petugas Kesehatan

\begin{tabular}{ccc}
\hline $\begin{array}{c}\text { Dorongan } \\
\text { Petugas } \\
\text { Kesehatan }\end{array}$ & Frekuensi & (\%) \\
\hline Buruk & 5 & 23,8 \\
\hline Sedang & 8 & 38,1 \\
\hline Baik & 8 & 38,1 \\
\hline Jumlah & 21 & 100 \\
\hline
\end{tabular}

Berdasarkan tabel diatas, diketahui bahwa sebagian besar dorongan petugas kesehatan yang diterima responden berada pada kategori baik yaitu sebanyak 8 responden $(38,1 \%)$, kategori sedang sebanyak 8 responden $(38,1 \%)$ dan kategori buruk 5 responden $(23,8 \%)$ dalam dorongan petugas kesehatan.

Tabel 4. Pengaruh Kepatuhan Penderita TB Paru dengan Tingkat Kesembuhan

\begin{tabular}{|c|c|c|c|c|c|}
\hline \multirow{2}{*}{ Variabel } & & \multicolumn{2}{|c|}{$\begin{array}{c}\text { Tingkat } \\
\text { Kesembuhan }\end{array}$} & \multirow[b]{2}{*}{$\mathrm{Jlh}$} & \multirow{2}{*}{$\begin{array}{c}P \\
\text { val } \\
\text { ue }\end{array}$} \\
\hline & & $\begin{array}{c}\text { Tdk } \\
\text { Sembuh }\end{array}$ & $\begin{array}{c}\mathrm{Se} \\
\mathrm{mb} \\
\mathrm{uh}\end{array}$ & & \\
\hline \multirow{5}{*}{$\begin{array}{l}\text { Kepatu } \\
\text { han }\end{array}$} & Tid & & & & \\
\hline & $\begin{array}{l}\text { ak } \\
\text { Pat }\end{array}$ & 6 & 0 & 6 & \\
\hline & uh & & & & \\
\hline & $\begin{array}{l}\text { Pat } \\
\text { uh }\end{array}$ & 3 & 12 & 15 & \\
\hline & $\begin{array}{l}\text { Jum } \\
\text { lah }\end{array}$ & 9 & 12 & 21 & \\
\hline
\end{tabular}

Berdasarkan hasil analisis uji statistik menunjukkan bahwa variabel kepatuhan memiliki pengaruh secara signifikan terhadap tingkat kesembuhan pengobatan TB Paru dengan nilai $p(0,002)<a(0,05)$. Berdasarkan tabulasi silang diatas menunjukkan bahwa dari 15 responden yang berada dalam kategori patuh sebesar $57,1 \%$ sembuh dalam pengobatan TB Paru dan dari 6 responden berada dalam kategori tidak patuh sebesar $28,6 \%$ sembuh.

Tabel 5. Pengaruh Dukungan Keluarga/PMO dengan Tingkat Kesembuhan

\begin{tabular}{|c|c|c|c|c|c|}
\hline \multirow{2}{*}{\multicolumn{2}{|c|}{ Variabel }} & \multicolumn{2}{|c|}{$\begin{array}{c}\text { Tingkat } \\
\text { Kesembuhan }\end{array}$} & \multirow{3}{*}{ Jlh } & \multirow{3}{*}{$\begin{array}{l}p \\
\text { va } \\
\text { lu } \\
e\end{array}$} \\
\hline & & Tdk & & & \\
\hline \multirow{5}{*}{$\begin{array}{l}\text { Kelua } \\
\text { rga/P } \\
\text { MO }\end{array}$} & & & & & \\
\hline & Buruk & 6 & 0 & 6 & \multirow{4}{*}{$\begin{array}{c}0, \\
00 \\
3\end{array}$} \\
\hline & $\begin{array}{l}\text { Seda } \\
\text { ng }\end{array}$ & 2 & 5 & 7 & \\
\hline & Baik & 1 & 7 & 8 & \\
\hline & $\begin{array}{l}\text { Jumla } \\
\text { h }\end{array}$ & 9 & 12 & 21 & \\
\hline
\end{tabular}

Berdasarkan hasil analisis uji statistik menunjukkan bahwa variabel dukungan keluarga/PMO berpengaruh signifikan dengan tingkat kesembuhan pengobatan TB paru terhadap nilai $p(0,003)<a(0,05)$. Berdasarkan tabulasi silang diatas menunjukkan bahwa sebanyak 8 responden yang termasuk dalam ketagori dukungan keluarga/PMO baik, sebanyak 33,3\% sembuh dalam pengobatan TB paru.

Tabel 6. Pengaruh Dorongan Petugas Kesehatan dengan Tingkat Kesembuhan

\begin{tabular}{|c|c|c|c|c|c|}
\hline \multirow[b]{2}{*}{ Variabel } & & \multicolumn{2}{|c|}{$\begin{array}{c}\text { Tingkat } \\
\text { Kesembuhan }\end{array}$} & \multirow[b]{2}{*}{ Jlh } & \multirow{2}{*}{$\begin{array}{c}P \\
\text { value }\end{array}$} \\
\hline & & $\begin{array}{c}\text { Tdk } \\
\text { Sembu } \\
\mathrm{h}\end{array}$ & $\begin{array}{l}\mathrm{Se} \\
\mathrm{mb} \\
\mathrm{uh}\end{array}$ & & \\
\hline \multirow{4}{*}{$\begin{array}{c}\text { Petugas } \\
\text { Kesehat } \\
\text { an }\end{array}$} & $\begin{array}{c}\text { Buru } \\
k\end{array}$ & 5 & 0 & 5 & \multirow{4}{*}{$\begin{array}{c}0,00 \\
8\end{array}$} \\
\hline & $\begin{array}{c}\text { Seda } \\
\mathrm{ng}\end{array}$ & 3 & 5 & 8 & \\
\hline & Baik & 1 & 7 & 8 & \\
\hline & $\begin{array}{l}\text { Juml } \\
\text { ah }\end{array}$ & 9 & 12 & 21 & \\
\hline
\end{tabular}

Berdasarkan hasil analisis uji statistik menunjukkan bahwa variabel dorongan petugas kesehatan memiliki pengaruh yang signifikan dengan tingkat kesembuhan dalam 
proses pengobatan TB paru karena nilai $\mathrm{p}$ $(0,008)<a(0,05)$.

Berdasarkan tabulasi silang diatas menunjukkan bahwa sebanyak 8 responden menerima dorongan petugas kesehatan dalam kategori baik, sebesar 33,3\% sembuh dalam pengobatan TB paru dan 5 responden berada dalam kategori buruk dalam menerima dorongan petugas kesehatan, sebesar $0 \%$ tidak sembuh dalam pengobatan TB paru.

\section{PEMBAHASAN}

Hasil analisis uji Chi-square pada tingkat kepercayaan 95\% dan alpha 0,05 diperoleh nilai $\rho$ value 0,002 artinya ada pengaruh yang bermakna antara kepatuhan penderita TB paru terhadap tingkat kesembuhan pengobatan penyakit TB paru.

Hasil penelitian ini mendukung penelitian yang sudah dilakukan oleh Indah (2011) yang menyatakan bahwa berhasilnya pengobatan dipengaruhi oleh kepatuhan penderita dalam menjalani pengobatan di Maluku Tenggara. Hasil penelitian ini juga sesuai dengan penelitian Mukhsin (2010) yang menyatakan bahwa keteraturan berobat mempunyai pengaruh yang kuat terhadap proses kesembuhan Tuberkulosis TB paru BTA positif di Propinsi Jambi.

Hasil penelitian ini menunjukkan bahwa sebagian besar responden $(71,4 \%)$ berada dalam kategori patuh dan responden dalam kategori tidak patuh ada 6 responden $(28,6 \%)$. Ada banyak hal atau alasan yang menyebabkan responden tidak patuh dalam menjalani pengobatan, diantaranya adalah pada saat minum obat, responden merasa bosan karena terlalu lama minum obat, serta jumlah dan ukuran obat terlalu banyak dan besar. Responden juga mengeluhkan lupa minum obat karena bekerja dan tidak ada yang menggantikan responden mengambil obat ke puskesmas.

Menurut pendapat Green bahwa perilaku kesehatan atau tingkat kesehatan seseorang ditentukan oleh sikap seseorang terhadap obyek kesehatan. Semakin baik sikap seseorang terhadap kesehatan maka tingkat kesehatan seseorang tersebut juga akan semakin baik. Kepatuhan seseorang dalam meminum obat dipengaruhi oleh sikap seseorang tersebut terhadap penyakit yang ia diderita. Hasil analisis uji statistik bivariat dalam penelitian ini, menunjukkan bahwa variabel dukungan keluarga/PMO memiliki pengaruh terhadap tingkat kesembuhan pengobatan TB Paru, yaitu $p=0,003<0,05$.

Hasil dari penelitian ini sesuai dengan hasil penelitian Sujana (2012), yang menyatakan bahwa PMO memiliki hubungan dengan hasil pengobatan TB Paru dan hubungan keluarga dengan penderita. Hasil penelitian ini juga sesuai dengan hasil penelitian Hendrawati (2012) yang menyatakan bahwa peran PMO sangat penting untuk proses kesembuhan seseorang penderita TB BTA positif karena hanya TB BTA positif yang bisa menularkan Penyakit TB kepada orang lain.

Berdasarkan hasil penelitian diketahui bahwa sebagian besar bahkan hampir semua PMO berasal dari keluarga responden sendiri dan penderita yang patuh berobat dan memeriksakan dahaknya ke Puskesmas sesuai dengan ketetapan yang telah disepakati dengan petugas, meskipun penderita tersebut tidak mendapatkan dukungan/PMO. Penderita TB tersebut selalu mengambil obat sendriri ke puskesmas dan tidak pernah digantikan oleh keluarga/PMO.

Hasil analisis uji bivariat diketahui bahwa variabel dorongan petugas kesehatan mempunyai pengaruh terhadap tingkat kesembuhan pengobatan TB paru, yaitu $p=0,008<0,05$. Hasil penelitian ini juga sesuai dengan penelitian Mulyadi (2010) yang menyatakan bahwa sikap petugas berpengaruh terhadap keberhasilan program penanggulang TB paru di Puskesmas Delanggu Kabupaten Klaten.

Hasil penelitian ini diketahui bahwa petugas yang menangani masalah TB di puskesmas Tanjung Morawa Kabupaten Deli Serdang melakukan kegiatan penanggulangan TB paru hanya berlangsung di Puskesmas dan tidak ada kegiatan penyuluhan TB di masyarakat. Petugas 
menyatakan bahwa OAT selalu tersedia di puskesmas dan penyuluhan dilakukan secara perorangan di Puskesmas .

Adanya komunikasi serta perhatian oleh petugas kesehatan dapat meningkatkan motivasi penderita Penyakit TB paru untuk patuh terhadap tingkat kesembuhan pengobatan .

\section{KESIMPULAN}

1. Kepatuhan responden di Puskesmas paling banyak kategori patuh yaitu 15 responden $(71,4 \%)$ dan kategori tidak patuh yaitu 6 responden $(28,6 \%)$.

2. Dukungan keluarga di Puskesmas paling banyak yaitu kategori baik 8 responden $(38,1 \%)$ dan kategori buruk $6(28,6 \%)$ dalam dukungan keluarga/PMO.

3. Dukungan Petugas di puskesmas bahwa sebagian besar dorongan petugas kesehatan yang diterima responden berada pada kategori baik 8 responden $(38,1 \%)$, dan kategori buruk 5 responden $(23,8 \%)$.

4. Ada pengaruh kepatuhan penderita TB paru terhadap tingkat kesembuhan pengobatan di Puskesmas Tanjung Morawa

5. Ada pengaruh dukungan keluarga/PMO dengan tingkat kesembuhan pengobatan TB paru di Puskesmas Tanjung Morawa

6. Ada pengaruh dorongan petugas kesehatan terhadap tingkat kesembuhan pengobatan di Puskesmas Tanjung Morawa.

7. Ada pengaruh motivasi penderita TB paru terhadap tingkat kesembuhan pengobatan di Puskesmas diketahui bahwa motivasi (dukungan keluarga/PMO dan dorongan petugas kesehatan) di Puskesmas Tanjung Morawa .

\section{DAFTAR PUSTAKA}

Amiruddin, R. 2011. Faktor Risiko Kegagalan Konversi Pada Penderita Tuberkulosis Paru BTA Positif Baru Di Kota Ambon Provinsi Maluku.
Dinas Kesehatan Provinsi Sumatera Utara. 2015. Laporan TB Paru Bid. P2PL Medan.

Dinas Kesehatan Kabupaten Deli Serdang. 2016. Laporan TB Paru Bid. P2PL.Deli Serdang.

Hendrawati, P.I, 2012. Hubungan Antara Partisipasi Pengawas Menelan Obat (PMO) Keluarga dengan Sikap Penderita Tuberkulosis Paru di Wilayah Kerja Puskesmas Banyuanyar Surakarta.Skripsi. UMS. Surakarta.

Indah, 2011. Evaluasi Faktor Penentu Kepatuhan Penderita TB Paru Minum OAT di Puskesmas Kabupaten Maluku Tenggara tahun 2011.Tesis. Pascasarjana UGM. Yogyakarta.

Kemenkes, RI, 2011. Pedoman Penanggulangan Tubercullosis, Jakarta ; Ditjen PPM-PLP

Kementrian Kesehatan Republik Indonesia 2013. Profil Kesehatan Insonesia.

Kementrian Kesehatan Republik Indonesia 2016. Profil Kesehatan Insonesia.

Mukhsin, Y. 2010. Faktor-faktor yang Mempengaruhi Keteraturan Minum Obat Pada Penderita TBC Paru yang Mengalami Konversi di Kota Jambi. Tesis UGM. Yogyakarta.

Mulyadi, 2010. Hubungan Kepatuhan Minum Obat Dengan Kesembuhan Pasien Tuberkulosis Paru BTA Positif di Puskesmas Delanggu Kabupaten Klaten.

Sujana. 2012. Motivasi Penderita Tuberkulosis Paru Dalam Minum Obat. http://abhique.blogspot.com. diakses tanggal 1 Mei 2013.

Walgito, B. 2009. Pengantar Psikologi Umum. PT.Andi. Yogyakarta. 